Ceccomori Silvia (2017) Les Ramoneurs lombards à Paris. Histoire d'une émigration séculaire

\title{
Ralph Schor
}

\section{(2) OpenEdition}

1 Journals

Édition électronique

URL : https://journals.openedition.org/remi/14726

DOI : $10.4000 /$ remi. 14726

ISSN : $1777-5418$

Éditeur

Université de Poitiers

\section{Édition imprimée}

Date de publication : 1 octobre 2020

Pagination : 175-176

ISBN : 979-10-90426-66-5

ISSN : 0765-0752

Référence électronique

Ralph Schor, « Ceccomori Silvia (2017) Les Ramoneurs lombards à Paris. Histoire d'une émigration séculaire », Revue européenne des migrations internationales [En ligne], vol. $36-n^{\circ} 1$ | 2020, mis en ligne le 01 octobre 2020, consulté le 15 avril 2022. URL : http://journals.openedition.org/remi/14726 ; DOI : https://doi.org/10.4000/remi.14726

Ce document a été généré automatiquement le 15 avril 2022.

(c) Université de Poitiers 


\title{
Ceccomori Silvia (2017) Les Ramoneurs lombards à Paris. Histoire d'une émigration séculaire
}

\author{
Ralph Schor
}

\section{RÉFÉRENCE}

Ceccomori Silvia (2017) Les Ramoneurs lombards à Paris. Histoire d'une émigration séculaire, Paris, L'Harmattan, 293 p., ISBN : 978-2-343-13457-4

1 Silvia Ceccomori, issue d'une famille de ramoneurs piémontais, a voulu éclairer l'histoire de ses ancêtres et plus particulièrement de ceux qui partirent du Val Vigezzo, proche de Domodossola (Italie).

2 La profession de ramoneur est née au XIIe siècle avec la généralisation des cheminées fixes, adossées aux murs et surmontées de conduits. Les représentants piémontais de cette activité sont à Paris depuis le XVe siècle. Certains d'entre eux exercent concurremment le métier de colporteurs et vendent de menus objets, de la quincaillerie, du cristal taillé, voire des bijoux. Ils partent à pied de chez eux, à l'automne, et gagnent Paris. Là, ils sillonnent les rues, lancent des cris d'appel et accompagnent leur travail par des musiques spécifiques. Les patrons emploient des enfants âgés de six à huit ans qui, grâce à leur petite taille, peuvent se glisser dans les conduits. Ces jeunes, mal nourris, mal logés, mal vêtus, sont exposés à de nombreuses maladies, fractures, asphyxie, absorption de suie et de gaz nocifs qui engendrent affections pulmonaires, asthme, dermatites, etc. Certains prêtres essaient d'améliorer la condition des jeunes par la charité et l'ouverture d'écoles. Mais les enfants continueront à exercer leur dangereuse activité jusqu'au début du XXe siècle.

Les ramoneurs les plus avisés travaillent dès le XVIIe siècle pour les rois de France dont les palais contiennent des milliers de cheminées. Parmi les clients figurent la marquise de Pompadour, la princesse de Monaco, le comte d'Artois, les Choiseul, etc. Au 
XVIIIe siècle s'organise la profession nouvelle de fumiste désignant non seulement le ramonage, mais aussi l'art de construire les cheminées, puis la vente et l'installation de poêles et de fourneaux. Certaines familles, travaillant pour l'aristocratie, constituent des entreprises modernes, accèdent à l'opulence, ainsi les Padelin, les Vernisse, les Bertolin, les Trabucchi, etc. Au début du XIXe siècle, la moitié des poêliers-fumistes de Paris sont italiens. Ils travaillent généralement en famille et sont liés par une étroite solidarité. Les plus prospères achètent des maisons de rapport, des terrains constructibles, surtout au moment de l'essor de Paris sous le IIe Empire.

4 L'ouvrage qui n'est pas dû à la plume d'une historienne professionnelle n'est pas exempt de critiques. On y relève quelques erreurs ; ainsi le baron Haussmann, préfet de la Seine, est désigné comme architecte. Le plan n'apparaît pas toujours rigoureux et logique. Mais l'auteur a effectué un louable travail de dépouillement : c'est une étude de première main appuyée sur des archives originales. Les ouvertures sur le théâtre, la poésie, l'iconographie, la musique se révèlent intéressantes. Ce livre fait revivre un milieu social peu connu, avec ses techniques de travail, ses stratégies économiques et familiales, ses valeurs. Une utile contribution à l'histoire sociale.

\section{AUTEURS}

\section{RALPH SCHOR}

Historien, Professeur émérite

Université de Nice-Sophia-Antipolis 